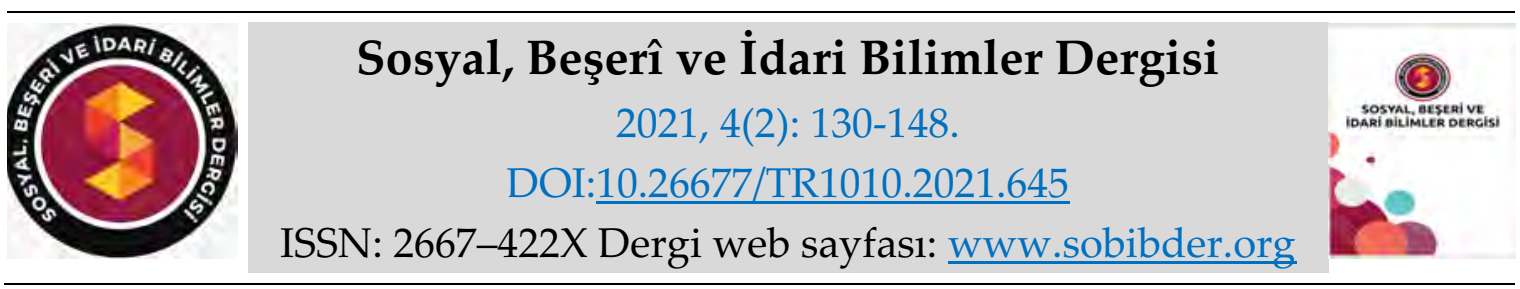

ARAȘTIRMA MAKALESI

\title{
Uluslararası Halkla İlişkiler Alanında Türkiye'de Yapılmış Akademik Çalışmalar Üzerine Bir İnceleme
}

Elifnur TERZİĞLU, Doktora Öğrencisi, Atatürk Üniversitesi, Sosyal Bilimler Enstitüsü, Erzurum, e-posta: elifnur_88@hotmail.com ORCID: https://orcid.org/0000-0002-3467-1537

Öz

Özellikle 1980'li yıllardan sonra dünyada teknoloji ve iletişim alanında meydana gelen gelişmeler, uluslararası ekonomik ilişkilerin yaygınlaşmasına neden olmuştur. Küreselleşen dünya ile sayıları ve etkileri artan çokuluslu şirketlerin dünya ekonomi sistemine ayak uydurması ve rekabet koşulları ile başa çıkabilmesi adına halkla ilişkiler faaliyetlerine verdikleri önem giderek artmaktadır. Fakat birçok farklı ülke ve kültürde faaliyet gösteren bu çokuluslu şirketler için halkla ilişkiler alanı yeterli olmamaktadır. "Küresel Köy" artık "Küresel Kent"e dönüşmekte ve süreç bizi, Uluslararası Halkla İlişkiler kavramına götürmektedir. Uluslararası halkla ilişkiler alanında yapılmış tezlerin konu edinildiği bu çalışmanın amacı Türkiye'de bu konuyla ilgili, bugüne kadar yapılmış olan tezleri betimleyici bir yaklaşımla analiz etmektir. Bu çalışma kapsamında yazılmış olan 9 tez çalışma evrenini oluştururken sayının az olması nedeniyle örneklem seçimine girilmemiş, tüm evren araştırmaya dâhil edilmiştir. Çalışma betimleyici olduğundan dolayı veri toplama tekniği de içerik analizidir. İncelenen tezlerde içerik analizi, derinlemesine mülakat ve anket yönteminin kullanıldığ tespit edilmiştir.

Anahtar Kelimeler: Halkla İlişkiler, Uluslararası Halkla İlişkiler, Kamu Diplomasisi, Küresel Köy, Doktora Tez.

Makale Gönderme Tarihi: 16.11 .2020

Makale Kabul Tarihi: 02.02.2021

\section{Önerilen Atıf:}

Terzioğlu, E. (2021). Uluslararası Halkla İlişkiler Alanında Türkiye'de Yapılmış Akademik Çalışmalar Üzerine Bir İnceleme, Sosyal, Beşeri ve İdari Bilimler Dergisi, 4(2): 130-148.

(c) 2021 Sosyal, Beşerî ve İdari Bilimler Dergisi. 


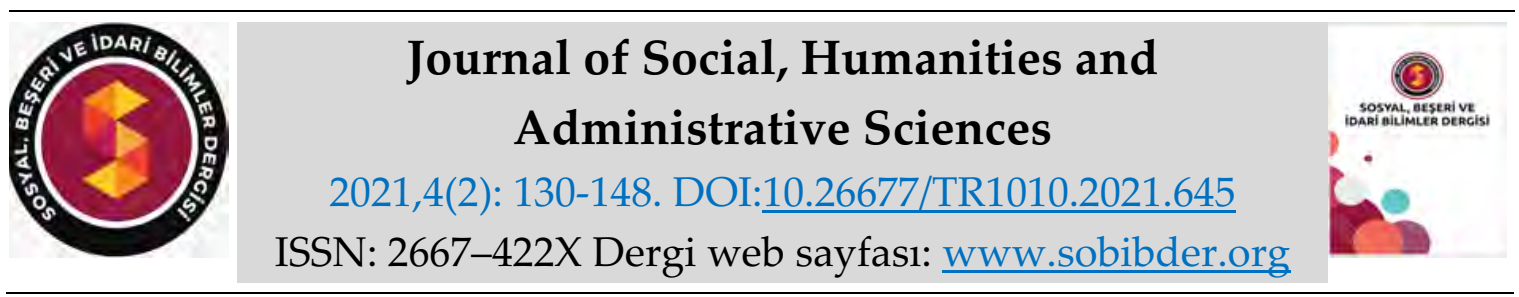

$\underline{\text { RESEARCH PAPER }}$

\title{
An Investigation on Academic Studies in The Field of International Public Relations in Turkey
}

Elifnur TERZIOĞLU, Ph.D. Student, Atatürk University, Social Sciences Institute, Erzurum, email: elifnur88@hotmail.com ORCID: https://orcid.org/0000-0002-3467-1537

\begin{abstract}
The developments in technology and communication in the world, especially after the 1980s, caused the spread of international economic relations. With the globalizing world, the importance of multinational companies increasing their number in public relations activities in order to keep pace with the world economy system and cope with competitive conditions. The "Global Village" is now turning into a "Global City" and the process takes us to the concept of International Public Relations. The purpose of this study, which is the subject of the dissertations in the field of international public relations in Turkey, descriptive thesis was to analyze the ever made an approach. While forming the working universe of 9 theses written within the scope of this study, the number of samples was not included in the selection, and the whole universe was included in the research. Since the study is descriptive, the data collection technique is content analysis. It was determined that content analysis, in-depth interview and survey method were used in the theses examined.
\end{abstract}

Keywords: Public Relations, International Public Relations, Public Diplomacy, Global Village, Doctoral Thesis.

Received: 16.11 .2020

Accepted: 02.02.2021

Suggested Citation:

Terzioğlu, E. (2021). An Investigation on Academic Studies in The Field of International Public Relations in Turkey, Journal of Social, Humanities and Administrative Sciences, 4(2): 130-148.

(C) 2021 Sosyal, Beşerî ve İdari Bilimler Dergisi. 


\section{Gíriş}

Kitle iletişim araçlarının kullanımının yaygınlaşması ile mesafeler azalmaya, sınırlar ortadan kalkmaya başlamaktadır. Giderek küçülen dünyada teknoloji sadece ekonomiye değil aynı zamanda ideolojilere de sınır tanımaz bir alan sağlamakta, ürünler, kültürler ya da fikirler ülkelerarası gidip gelmeye, yerel çapın ötesinde uluslararası arenada kendilerine yer edinmeye başlamaktadır. Geçmişte sadece ulusal olan olgular, olaylar ya da ticari kuruluşlar teknoloji ile uluslararası çapta tanınır hale gelmekte, dünyanın bir ucunda yaşanan skandal, üretilen bir ürün, alınan bir karar dünyanın diğer ucundaki toplumlar tarafından anında öğrenilmektedir. Zira artık yerel ve uluslararası kavramlar iç içe geçmekte ve McLuhan'ın "küresel köy"ü "küresel kent"e dönüşmektedir (McLuhan, 2001: 15) Toplum artık küresel iletişimin rutin sürecine dahil olma imkanı sağlayan teknolojiye bağımlı olma eğilimi göstermektedir. Küreselleşme kavramı bu eğilimle birlikte kendini özellikle sosyal, kültürel, eğitsel, siyasal ve ekonomik alanlarda hissettirmeye başlamakta ve bu alanlarda önemli değişimlere de neden olmaktadır. İletişim faaliyetlerini de etkileyen küreselleşme, çalışmanın konusunu oluşturan ve sosyal bilimler alanı olan uluslararası halkla ilişkilere de önemli bir boyut kazandırmaktadır. Bu kapsamda uluslararası ilişkiler ve halkla ilişkiler kavramlarının yakınlaştığı görülmektedir. Uluslararası ilişkilerin sadece devletlerarası yürütülen diplomatik ilişkilerden ibaret olmadığı, ülke vatandaşları ile kurulan bir iletişim faaliyeti olduğu da anlaşılmaktadır. Hükümetlerin, kurum ya da kuruluşların nitel ve nicel yönden çeşitlenen hedef kitleler ile kurduğu iletişimin karmaşık hale gelmesi uluslararası halkla ilişkilerin önemini artırmaktadır. Uluslararası halkla ilişkiler diplomasiden pazarlamaya kadar birden fazla alanı içinde barındıran bir kavram haline gelmektedir.

Uluslararası halkla ilişkiler alanında yapılmış tezlerin konu edinildiği bu çalışmanın amacı Türkiye' de bu konuyla ilgili, bugüne kadar yapılmış olan tezleri betimleyici bir yaklaşımla analiz etmektir. Bu amaç doğrultusunda YÖK'ün Ulusal Tez Tarama Merkezi'nde, "uluslararası halkla ilişkiler" kavramı şeklinde tarama yapıldığında toplam 9 adet tezin var olduğu tespit edilmiştir. $\mathrm{Bu}$ tezlerin sadece halkla ilişkiler disiplini içerisinde çalışıldığı görülmüştür. Bu çalışma kapsamında yazılmış olan 9 tez çalışma evrenini oluştururken sayının az olması nedeniyle örneklem seçimine girilmemiş, tüm evren araştırmaya dâhil edilmiştir. Çalışma betimleyici olduğundan dolayı veri toplama tekniğini de içerik analizidir. Bu tezlerde uluslararası halkla ilişkiler bağlamında; kavramsal olarak uluslararası halkla ilişkiler, uluslararası halkla ilişkilerin aktörleri ve alanla ilgili kilit kavramlar üzerinde durulmuş ve bu konular detaylı olarak ele alınmıştır. İncelenen tezlerde içerik analizi, derinlemesine mülakat ve anket yönteminin kullanıldığı tespit edilmiştir.

\section{ULUSLARARASI HALKLA İLİŞKİLER}

Tench veYeomans'a göre (2006: 130) günümüz iletişim dünyasında, devletlerin kamu diplomasisi çalışmalarını içeren ve diğer ulusları hedef alan iletişim faaliyetleri uluslararası halkla ilişkiler kavramı altında ele alınmaktadır. Fakat uluslararası halkla ilişkiler kavramına değinmeden önce halkla ilişkiler tanımlarına göz atmak faydalı olacaktır. Çünkü uluslararası halkla ilişkiler, halkla ilişkilerin uluslararası boyuta taşınması olarak değerlendirilebilir fakat halkla ilişkilerden farkı, iletişim kurduğu ve faaliyet yürüttüğü hedef kitlenin uluslararası olarak genişlemesidir. Bu genişleme hedef kitleler arasında algı ve tutumda, fikirlerde, beklenti ve isteklerde çeşitliliği ve farklılığ1 da getirmektedir. Holtzhausen (2011: 146), küresel halkla ilişkiler kavramı ve uluslararası halkla ilişkiler kavramının oldukça farklı uygulamalar olduğunu ifade etmektedir. Lassalle'nin 1959 yılındaki “Uluslararası Halkla İlişkilerdeki Sorunlar" adlı makalesinde diğer insanların bizden farklı olduğu ve bu farklılığın farklı beklentiler oluşturduğu bu nedenle de 
uluslararası halkla ilişkilerin daha karmaşık bir yapı haline dönüştüğü ifade edilmektedir. Uluslararası halkla ilişkilerin hedef kitlesindeki bu genişlik ve çok yönlülük üzerinde daha titiz çalışılması gerektiği belirtilmektedir (Lassalle, 1959: 5-6).

Halkla ilişkilerle ilgili literatür incelendiğinde çok sayıda tanıma rastlamak mümkündür. Çok sayıda tanımın olmasına rağmen tanımlar çoğunlukla benzerlik göstermektedirler (Arklan ve Akdağ, 2010: 3). 1976 yılında Harlow'un halkla ilişkilerle ilgili olarak 472 farklı tanımı karşılaştırıp konu üzerinde çalışmalar yaptığı düşünüldüğünde (Akdağ, 2010: 36), 1976 yılından günümüze kadar bu alandaki araştırmacıların artışı ve konunun daha da popülerleşmesi göz önüne alındığında, halkla ilişkilerin sayısız tanıma sahip olduğundan söz edilebilir. Fakat genel olarak halkla ilişkilerin günümüzde kamu ve özel sektörlerde, kar amacı güden ya da gütmeyen tüm organizasyonlarda kitleler arasında çift yönlü iletişimini planlayan, arzu edilen şekilde ilişkilerin yürütülmesini sağlayan ve kullanımı gittikçe yaygınlaşan bir yönetim fonksiyonu olduğu bilinmektedir. Yine bu tanımlamaların tümünde ortak olan bir nokta ise halkla ilişkilerin anlaşmazlıkları çözme çabasına dayanan bir faaliyetler bütünü olmasıdır. Teknolojinin ilerlemesinin dünyanın sonunu getirecek bir güce sahip olduğunu ve bu nedenle savaşların ya da krizlerin yaşanmasının daha mümkün hale geldiğini ifade eden Hiebert (2005: 318), bu tür krizlerin ancak anlaşmazlıkların giderilmesiyle engellenebileceğini bu süreçte de halkla ilişkilere görev düştügünü belirtmektedir. Halkla ilişkilerin birleştirici gücüyle karşlıklı ortak bir dilde konuşmak, dinlemek, anlamak en önemlisi de anlaşmazlıkları gidermek mümkün hale gelmektedir.

Moore ve Kalupa (1985: 538) halkla ilişkilerin Amerikan dünyasına 20. yy. ilk yarısında girdiği ve tanımı konusunda kargaşa yaşandığını ifade etmiştir. Aynı yüzyılın ikinci yarısında ise uluslararası halkla ilişkilerin ortaya çıktığından ve bu kavramın tanımlamasında da aynı sıkıntıların yaşandığından söz etmişlerdir. Halkla ilişkiler hem uygulandığı alanlar bakımından hem de sınırları bakımından giderek genişlemekte ve ulusal sınırların dişında da kullanılması söz konusu olmaktadır. Uluslararası ilişkilerin son elli yıldan beri gelişmesiyle, dünya gittikçe küçülmüş ve artık hiçbir ulus ve kültür, diğerleriyle ilişkisini keserek yaşamını sürdüremez hale gelmiştir (Kartarı, 2000: 40). Halkla ilişkiler, örgütlerin hedef kitlelerine kolayca ulaşması için stratejik bir uygulama yürütmekte ve bunun yanında değişen iletişim süreci sebebiyle de yeni nitelikler kazanmaktadır. Sriramesh ve Vercic'e göre, uluslararası iletişimin giderek yoğunlaşması, halkla ilişkiler uzmanlarına birçok uluslararası ve kültürler arasındaki ilişkileri yürütme gibi bir amaç eklemiştir (Sriramesh ve Vercic, 2002: 104). Dünyada yaşanan bu ekonomik, politik, kültürel ve teknolojik gelişmelerden etkilenen iletişim sektöründe kilit rol oynayanlardan biri olan halkla ilişkilerin giderek küresel köye dönüşen dünyaya kayıtsız kalması söz konusu değildir. Halkla ilişkiler faaliyetlerinin uluslararası boyuta ulaşmasındaki en önemli unsur kurumsal ve bireysel etkileşimin uluslararası alana yayılmaya başlaması olmuştur. Günümüzde hükümetler, özel ya da resmi şirketler uluslararası örgütlerle, halkla ilişkiler ve iletişim faaliyetlerini yürütmek için kendi halkla ilişkiler birimlerini faaliyete geçirmekte veya uluslararası alanda çalışan halkla ilişkiler firmalarından yardım almaktadırlar (Köksoy, 2013: 337). Günümüz küresel pazarında sesini duyurabilmek ve geleceğe yönelik fayda sağlamak adına, giderek yaygınlaşan üniversiteler ve kar amacı gütmeyen kuruluşlar, ajanslar ve dernekler uluslararası halkla ilişkilere yapılan yatırımın çok önemli olduğunu fark etmektedirler (Phair, 2011: 18). Uluslararası halkla ilişkiler faaliyetlerinde bulunmayan özel kuruluşlar, ekonomik rekabet şartlarına uyum sağlayamamakta, kamu kurumlarında ise bu durum ülkelerini ilgilendiren fırsatları kaçırmak ve imaj zedelenmesi ile sonuçlanmaktadır (Okay ve Okay, 2001: 297).

Bu noktadan hareketle, halkla ilişkilerin globalleşme neticesinde kazandığı bir pratik olarak adlandırılan uluslararası halkla ilişkileri, bir hükümetin diğer hükümet halkları ile karşılıklı çıkar 
ilişkilerini gerçekleştirme amacıyla planlı ve örgütlü çabası olarak tanımlamak mümkündür (Wilcox ve Cameron, 2006: 519). Benzer bir başka tanıma göre uluslararası halkla ilişkiler bir hükümet, şirket ya da özel veya kamu kuruluşunun bir başka devlet içerisindeki toplumlarla karşılıklı anlayış oluşturarak iletişim ortamı yaratma, olumlu imaj oluşturarak tanınırlığa katkıda bulunma ve itibar geliştirmeye yönelik yapılan detaylı bir stratejik iletişim planıdır (Yıldırım, 2015: 5). Culbertson (2009: 2) uluslararası halkla ilişkilerin, halkla ilişkiler uygulamasına uluslararası ve kültürlerarası biçimde yaklaştığını ve uluslararası örgütler, hükümetler arası ilişkiler, ulus ötesi ekonomik işler ve farklı ulusların vatandaşları arasındaki ilişkileri kapsadığını söylemektedir. Tanımlamalardan da görüleceği üzere, uluslararası halkla ilişkilerin temel aktörleri, uluslararası sivil toplum örgütleri, çok uluslu kuruluşlar, devletlerarası örgütler, ulus devletler ve hükümetler, halkla ilişkiler uygulayıcılarıdır ve sadece işletmeler açısından ele alınmıyor olması, ulus ötesi örgütlerin de göz önünde bulundurulması, iletişim faaliyetlerinin çok yönlülüğünü ifade etmesi açısından önemlidir. (Tench ve Yeomans, 2006: 116).

Grunig ve Hunt'ın geliştirdiği halkla ilişkiler modellerinden iki yönlü asimetrik modeli ile uluslararası halkla ilişkilerin olumlu ve karşılıklı anlayışa dayanan bir ortam yaratmayı amaçlaması arasında bir bağ vardır. Günümüzde de ideal olarak tanımlanan modellerden iki yönlü asimetrik modelde esas olan mesaj ve geribildirimin sürekliliğini sağlarken üretilen faydanın da iki yönlü olması amaçlanmaktadır. Hükümetlerin uluslararası halkla ilişkiler uygulamalarını yürütmesindeki amaç da kendi sosyal kültürel ve demokratik değerlerinin, ekonomik alanlarda olası fırsatların, siyasi arenada hem iç hem de diş politika hususlarının uluslararası kamuoyunda karşılıklı fayda doğrultusunda doğru şekilde ifade edilmesidir.

Uluslararası halkla ilişkiler faaliyetleri yürütülürken, faaliyetin uygulanacağı bölgenin değerleri, kültürü ve ideolojilerinin göz önünde bulundurulması gerekmektedir. Her ne kadar küreselleşme ile iletişim teknolojilerinde yaşanan gelişmeler ve yenilikler tüm kesimlerce ortak araç olarak kullanılsa da bu kesimlerin sahip oldukları değerler, inanç ve kültürlerin farklılaşması nedeniyle her ülke için uygulanan halkla ilişkiler programı değişmektedir (Okay ve Okay, 2001: 268). Bu nedenle bir ülkenin halkla ilişkiler faaliyetlerini etkileyen bazı unsurlar vardır: Coğrafi konum, ekonomik, politik, medya ve hukuki yapısı gibi çevresel faktörler uluslararası halkla ilişkiler faaliyetlerinde göz ardı edilemez (Pratt ve Ogbondah, 1996: 391).

\section{YÖNTEM}

Bu çalışmanın genel amacı uluslararası halkla ilişkiler konusunda Yüksek Öğretim Kurumu'nun ulusal tez tarama sayfasından ulaşılan tezlerin incelenerek alandaki araştırmacıların konuyu nasıl değerlendirdikleri ve hangi sonuçlara ulaştıklarını belirlemektir. Bu açıdan çalışmayla birlikte; tezlerin hangi bilim dallarında yazıldığı, tezlerde incelenen temel kavramların neler olduğu, siyasal iletişime ek olarak hangi konuların ele alındığı, hangi araştırma yaklaşımının kullanıldığı, tezlerin içerik açısından zenginlik düzeyleri, hangi veri toplama tekniğinin kullanıldığı, tezlerde uluslararası halkla ilişkilere ilişkin tutum ve yaklaşımın nasıl olduğu, hangi sonuçlara ulaşıldığı gibi konulara cevaplar aranmıştır.

Yapılan bu araştırma kapsamında evreni uluslararası halkla ilişkiler alanında yazılmış olan 9 tez oluştururken sayının az olması nedeniyle örneklem seçimine girilmemiş, tüm evren araştırmaya dâhil edilmiştir. Araştırma betimleyici bir yaklaşıma sahiptir ve analizde içerik analizi yöntemi kullanılmıştır. YÖK'ün Ulusal Tez Merkezi internet sayfasının ana sayfasında yer alan arama kısmına uluslararası halkla ilişkiler yazılarak arama yapılmış ve sonucunda 9 adet tez sonucuna ulaşılmıştır. Uluslararası halkla ilişkileri konu alan bu tezlerin tümü araştırmaya dahil edilmiş ve ayrıntılı bir şekilde irdelenmiştir. 
Tablo 1. Uluslararası Halkla İlişkiler Alanında Yazılmış Tezler

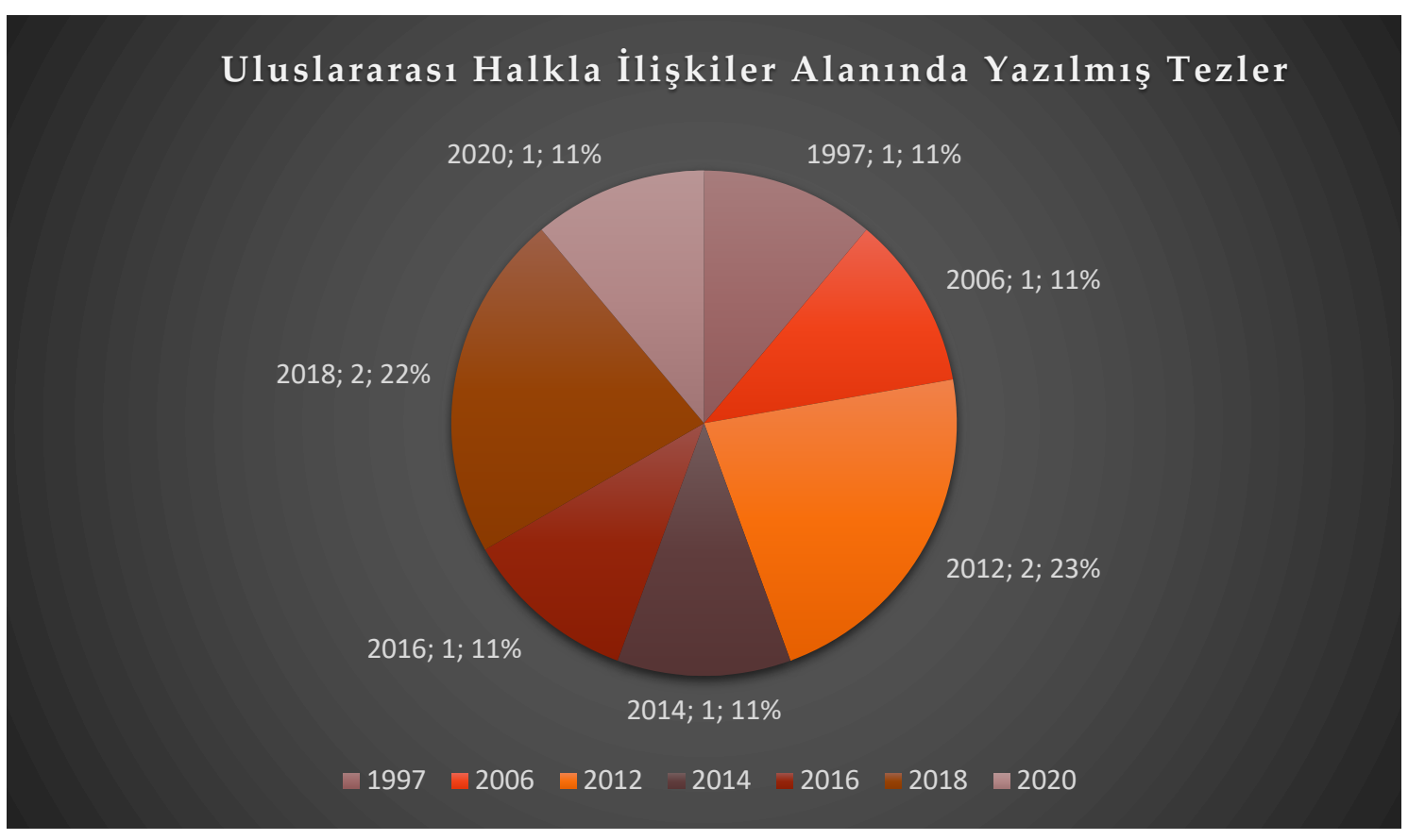

Kaynak: Ulusal Tez Merkezi resmi sayfasından alınan verilerinden hazırlanmıştır (www.tez.yok.gov.tr)

\section{ULUSLARARASI HALKLA İLIŞKILER ALANINDA TÜRKIYYE'DE YAPILMIŞ TEZLERIN İNCELENMESI}

\section{Nadide Aslı Dede'nin Yüksek Lisans Tezi}

Uluslararası halkla ilişkiler konusunda iletişim alanında yapılan ilk tez İstanbul Üniversitesi Sosyal Bilimler Enstitüsü İletişim Fakültesi Halkla İlişkiler ve Tanıtım Bilim Dalı'nda Nadide Aslı Dede tarafından, 1997 yılında "Uluslararası Halkla İlişkilerde “Küresel Düşün Fakat Yerel Davran" ve Levi Strauss \& Co. Türkiye Örneği" başlığı ile yazılan tezdir. Bu çalışma, konunun iletişim boyutuna değinmekte ve Türkiye'de bir iletişim fakültesi bünyesinde yazılmış ilk tez olma özelliği taşımaktadır.

Yazar, giriş, iki bölüm ve sonuçtan oluşan 116 sayfalık bu çalışmanın temel amacının uluslararası ticaretin gelişmesiyle birlikte önem kazanan uluslararası halkla ilişkiler alanında ileri sürülen yöntemlerin incelenmesi olduğunu ifade etmiştir. Çalışmanın birinci bölümünde ilk olarak uluslararası halkla ilişkiler kavramı detaylı şekilde anlatılmış, sanayi ve iletişim devriminin etkisiyle birlikte gelişen bu alanın önemine vurgu yapılmıştır. Uluslararası etkinlik gösteren halkla ilişkiler kuruluşları üzerinde durulmuş, Uluslararası Halkla İlişkiler Derneği'nin bu alana desteğine değinilmiştir. Çalışmanın birinci bölümünün ikinci alt başlı̆̆ında küresel yöntemleri savunan ve McLuhan'ın "küresel köy" fikrinden yola çıkan "Küreselleştirme Yaklaşımı", yerel değerlere göre yöntem oluşturulmasını savunan "Yerelleştirme Yaklaşımı" ve bu iki yaklaşımın sentezi olan "Uzlaşmacı Yaklaşım" incelenmiştir (Dede, 1997: 27). Bu bağlamda birbirine zıt yöntemleri savunan bu yaklaşımlar arasındaki savlar karşılaştırılmıştır. İkinci bölümde teorik olarak açıklanan kavramlar örneklerle detaylı şekilde ele alınmıştır. Öncelikle uluslararası alanda halkla ilişkiler faaliyeti gerçekleştirmek isteyen firma veya bireylerin kültüre yabancı olmalarından dolayı yaşadıkları sorunlara değinilmiştir. Özellikle Japonya ve Ortadoğu olmak 
üzere farklı ülkelerde bulunan halkla ilişkiler faaliyetleri incelenmiş ve uluslararası halkla ilişkilerde yaşanan veya yaşanması olası olan durumlar tartışılmıştır. "Küresel Düşün fakat Yerel Davran" yöntemini izleyen ve uluslararası halkla ilişkiler ağı kuran iki firma: Amerikan ilaç firması "The Upjohn Co." ve çok uluslu şirket "Levi Strauss \& Co." nun çalışmalarına değinilmiştir. Levi Strauss \& Co şirketinin Türkiye'de uyguladığı halkla ilişkiler stratejisi incelenmiş ve Türkiye'ni reklam süpervizörü BEC Group BTL Communication International Public Relations Group Genel Müdürü ile yapılan görüşme sonucunda, şirketin “Küresel Düşün fakat Yerel Davran" yöntemini benimsediği gözlemlenmiştir.

Yazar sonuç ve değerlendirme bölümünde uluslararası halkla ilişkilerin önemini bir kez daha vurgulamış ve uluslararası çalışan şirketlerin uluslararası pazarlama, reklam ve halkla ilişkiler alanında önem kazandığını ifade etmiştir. Bu nedenle halkla ilişkilerin sadece ulusal değil uluslararası arenada da gelişimini sağlamak amacıyla uluslararası kuruluşların oluş̧urulduğunu ve bunların başında Londra'da kurulan Uluslararası Halkla İlişkiler Derneği'nin geldiğini belirtmiştir. Uluslararası halkla ilişkiler yöntemlerinden, küreselleştirme ve yerelleştirme yaklaşımlarının sentezi olan uzlaşmacı yaklaşımın uluslararası halkla ilişkiler alanında şirketlere yardımcı olabilecek en etkili yöntem olduğu vurgusu yapılmıştır. Konuyla ilgili olarak seçilen örnek Levi Strauss \& Co. incelenmiş ve şirketin halkla ilişkiler çalışmalarında küresel ve yerel değerlerin uzlaşma içerisinde olduğu sonucuna varılmıştır.

\section{Sibel Karakaya'nın Yüksek Lisans Tezi}

Sibel Karakaya'nın 2006 yılında Akdeniz Üniversitesi Sosyal Bilimler Enstitüsü Halkla İlişkiler ve Tanıtım Anabilim Dalı'nda hazırladığı, “Uluslararasi Halkla Ilişkiler: Antalya'da Küçük ve Orta Ölçekli Işletmeler İle T.C. Yurtdisi Ticaret ve Ekonomi Müşavirlikleri'nde Bir Araştirma" başlıklı tezi, uluslararası halkla ilişkiler konusunda küçük ve orta ölçekli işletmelerin uluslararası halkla ilişkiler faalieyetlerine yönelik bir çalışma olmaması nedeniyle alana katkı sağlamıştır. Yazar, giriş, üç bölüm, değerlendirme ve sonuçtan oluşan 100 sayfalık bu çalışmaya bir de İngilizce özet eklemiştir. Karakaya, çalışmanın temel amacının uluslararası halkla iliskiler faaliyetlerinde göz önünde bulundurulması gereken unsurların önem derecelerini ve Antalya'da bulunan küçük ve orta ölçekli ihracatçı işletmelerin uygulamalarını belirlemek olduğunu ifade etmiştir.

Yazar, uluslararası halkla ilişkiler kavramını ele aldığı birinci bölümde, halkla ilişkilere küresel açıdan bakmak gerektiğini vugulamış, bu alanın kültürlerarası iletişimden ayrılan yanları olduğunu belirtmiş ve uluslararası halkla ilişkiler kavramını tanımlamaya çalışmıştır. Uluslararası halkla ilişkiler çalışmalarını etkileyen değişkenlerin hedef ülke profili, hedef ülkenin kültür yapısı ve iletişim profili olduğunu ifade eden Karakaya (2006: 25), uluslararası halkla ilişkilerde hedef kitle kimdir sorusuna cevap olarak kar amacı güden/gütmeyen, özel/kamusal kurumlardan bahsetmiştir. Çalışmanın ikinci bölümünde küçük ve orta ölçekli işletmelerden bahsedilmiş, küçük ve orta ölçekli işletme kriterleri belirlenerek, bu işletmelerin uluslararası pazarlara girerken karşılaştıkları zorluklar açıklanmaya çalışılmıştır. Uluslararası halkla ilişkileri etkileyen unsurların, Antalya' da ihracat yapmakta olan küçük ve orta ölçekli işletmeler için önem dereceleri anket sorularıyla ölçülmeye çalışılmış bu da üçüncü yani araştırma bölümünde belirtilmiştir. Antalya'nın seçilme nedenini turizm sektöründeki gelişmişliğine bağlayan yazar, ülke ekonomisinde yaygın ve önemli bir yer tutan küçük ve orta ölçekli işletmeler üzerine yaptığı bu çalışmanın alana katkı sağlayacağını belirtmiştir.

Araştırma bölümünde yazar Yurtdışı Ticaret ve Ekonomi Müşavirlikleri'ne uyguladığı anket sonuçlarının bir bölümünü, daha önce bu konuda yapılan çalışmaların sonuçlarıyla karşılaştırmış ve Antalya'da bulunan küçük ve orta ölçekli işletmelerin ihracata yönelik girişimlerinde 
kullandıkları uluslararası halkla ilişkiler faaliyetlerine ilişkin bir durum tesbiti yapmaya çalışmıştır. Karakaya, araştırmanın örneklemini oluşturan 89 işletmeden 37 cevap formu, 49 Yurtdışı Ticaret ve Ekonomi Müşavirlikleri'nden ise 31 cevap form elde etmiş ve verileri SPSS programında değerlendirmiştir. Anket sorularını firmaların profilini belirlemek adına çoktan seçmeli ve açık uçlu sorulardan, uluslararası halkla ilişkiler faaliyetlerini etkileyen unsurları ölçmek için derecelendirme sorularından ve işletmelerin yurt dışına yönelik yürüttükleri tanıtım faaliyetlerini belirlemek için iki seçenekli sorulardan hazırlamıştır. Yazar anket sorularının analizinde tanımlayıcı istatistiksel yöntemlerden frekans dağılımları, yüzdeler, çapraz tablolar gibi betimleyici istatistiklerle korelasyon analizleri kullanmış, sonuçları ise tablolar ile ifade etmiştir.

Çalışmanın araştırma sonuçlarını sonuç kısmında değerlendiren yazar, Antalya'da faaliyet gösteren ve ihracat yapmakta olan küçük ve orta ölçekli işletmelerin her ne kadar yurtdışında tanındıklarını ifade etmelerine rağmen, bu işletmelerin halkla ilişkiler uzmanı çalıştırmadıklarını ve ajans hizmetleri satın almadıklarını ifade etmiştir. İhracat yapmakta olan küçük ve orta ölçekli firmaların kendilerini tanıtmak için en çok uyguladıkları yöntemin web sitesi olduğunu belirten yazar, bu işletmelerin sıklıkla uyguladıkları diğer uluslararası halkla ilişkiler faaliyetlerinin yurtdışı ziyaretleri ve ikili görüşmelerin yapılması, yabancı dilde tanıtım broşürlerinin kullanılması, uluslararası sektörel fuarlara katılması, internette ilan ve reklam verilmesi, adrese postalama yapılması ve yurt dışındaki yabancı ticaret odaları ile temas kurulması olduğunu ifade etmiştir. Sonuç olarak yazar, Antalya' da faaliyet gösteren ve ihracat yapmakta olan küçük ve orta ölçekli işletmelerin çoğunun, uluslararası pazarlarda teknoloji ve tanıtım etkinlikleri sayesinde halkla ilişkilerin gücünden yararlandığını belirtmiştir.

\section{Zeynep İmrak'in Yüksek Lisans Tezi}

2012 yılında İstanbul Üniversitesi İletişim Fakültesi Halkla İlişkiler ve Tanıtım Anabilim Dalı'nda, Doç .Dr. Yıldız Dilek Ertürk danışmanlığında "Çokuluslu İşletmelerde Uluslararası Halkla İlişkiler Faaliyetleri: Taşımacıllk Sektöründen "Deutsche Post DHL" Üzerine Bir İnceleme" isimli tezin amacının İmrak, çok uluslu işletmelerde hangi halkla ilişkiler faaliyetlerinin uygulandığının belirtilmesi ve bu faaliyetler esnasında Grunig ve Hunt'in halkla ilişkiler modellerinden hangilerinin işletmelerin başarısı açısından daha etkin olacağının incelenmesi olduğunu ifade etmiştir. Yazar giriş, dört ana bölüm ve tartışma/sonuç kısmından oluşan 121 sayfalık tezinde ilk olarak küreselleşme kavramından bahsetmiş, küreselleşmenin iletişim boyutunu Mc. Luhan'ın küresel köy kavramı ile birlikte ele almıştır. Kültür kavramını detaylı inceleyen yazar kültürlerarası iletişimde yaşanan zorluklardan da bahsetmiştir.

Tezin ikinci bölümünde uluslararası halkla ilişkiler kavramını detaylı ele almadan önce halkla ilişkiler kavramını inceleyen yazar uluslararası halkla ilişkileri uygulayan kuruluşları da bu bölümde ele almıştır. Üçüncü bölümde ise çok uluslu işletmelerde artan rekabetle birlikte önemi bir kez daha öne çıkan uluslararası halkla ilişkiler faaliyetlerini inceleyen İmrak (2012: 69), bu faaliyetleri sponsorluk, kurumsal sosyal sorumluluk, kriz halkla ilişkileri, lobicilik ve diğer organizasyonlar olarak ayırmış ve tek tek ele almıştır. Uluslararası halkla ilişkilerde yaşanan zorlukları kültürel yapı, dil, hükümet yapısı ve medya ile olan ilişkiler olarak ele alan bu çalışmanın örneklemini çokuluslu bir şirket olan Deutsche Post DHL'nin uluslararası halkla ilişkiler faaliyetleri oluşturmuştur. Bu firmanın örneklem olarak seçilmesinin sebebini çokuluslu bir işletme olarak dünyada tanınırlığının yüksek olmasına ve Türkiye'de faaliyet göstermesine bağlayan yazar, konu ile ilgili örnek olaylara da yer vermiştir. 
Sonuç kısmında yazar halkla ilişkiler birimlerinin konumlandırılması gereken noktanın üst yönetim kadrosu veya baskın koalisyonda olması gerektiğini ve çokuluslu işletmelerin Grunig ve Hunt'ın halkla ilişkiler modellerinden çift yönlü simetrik modelini kullanmalarının başarıya ulaşmada etkili olduğunu ifade etmiştir. Uluslararası halkla ilişkiler faaliyetlerinin başarıya ulaşmasında farklı kültürlerin tanınmasının önemli olduğunu vurgulayan yazar, çokuluslu işletmelerin bünyelerinde halkla ilişkiler uzmanlarını çalıştırmaya başladıklarını ve bu alana daha çok yöneldiklerini belirtmiştir. İmrak, sosyal sorumluluk projelerinin, kültür ve sanat etkinliklerinin, oluşturulan küresel sloganların kültürlerarası iletişim bağlamında çokuluslu şirketlerin kullandığı yöntemler olduğunu ifade etmiştir. Nadide Aslı Dede'nin (1997: 28) tezinde savunduğu "Küresel Düşün Yerel Davran" kavramının tek başına yetersiz olduğunu, hem "küresel düşün yerel davran" hem de "yerel düşün küresel davran" fikrinin sentezlendiği bir yaklaşımın başarıya ulaşmada daha etkili olacağını savunmuştur. Yazar, araştırma örneğini oluşturan DHL firmasının uluslararası halkla ilişkiler faaiyetlerini planlarken bu iki düşünceyi benimsediğini ve oldukça başarılı sonuçlar elde ettiğini gözlemlemiştir. Sonuç olarak çokuluslu şirketler için uluslararası halkla ilişkiler faaliyetlerinin kilit rol oynadığı sonucuna varılmıştır.

\section{Tarık Kodal'ın Yüksek Lisans Tezi}

Tarık Kodal'ın 2016 yılında Erciyes Üniversitesi Sosyal Bilimler Enstitüsü Halkla İlişkiler ve Tanıtım Anabilim Dalı'nda, “Uluslararası Halkla Ilişkiler Bağlamında Yumuşak Güç: Üç Hedef Kitle Üzerine Bir Araştırma" başlıklı tezi giriş, üç bölüm, sonuç ve ingilizce özet olmak üzere 105 sayfadan oluşmaktadır. Yazar çalışmada, uluslararası halkla ilişkiler kavramını kamu diplomasisi ve yumuşak güç kavramları altında incelemiştir. Türkiye'nin yumuşak gücünün iç hedef kitle olarak ele alınan Türkiye'de yaşayan vatandaşlar tarafından bilinirliğinin ortaya konulmasını ve vatandaşların hangi konularda çalışmalara destek verdiğinin incelenmesini amaçlamıştır. Kodal (2016: 79), çalı̧̧manın evrenini basit tesadüfi yöntemle seçtiği Kayseri'nin merkez ilçelerinde yaşayan bireyler olarak belirtmiş ve örneklemini ise 20-31 Aralık 2015 yılında Kayseri'nin üç merkez ilçesinde ikamet eden bireylerden oluşturmuştur. Yazar çalışmasında niceliksel araştırma yöntemlerinden anket çalışmasını kullanmıştır.

Çalışmanın ilk bölümüde halkla ilişkilerin uluslararasılaşmasına, uluslararası halkla ilişkiler kavramına değinilmiş, küreselleşme olgusu, itibar yönetimi, ülke imajı ve uluslararası ilişkiler disipliniyle olan ilişkisi tartışılmıştır. Yazar ayrıca bu alandaki çalışmalarda Amerika etkisini de ele almıştır. İkinci bölümde yumuşak güç ve kamu diplomasisi konuları genel hatlarıyla incelenmiş, dünyadaki diğer ülkelerin başlıca uygulamaları ve Türkiye"nin bu bağlamda kurmuş olduğu kurum ve kuruluşlara ve bunların çalışmalarına yer verilmiştir. Üçüncü bölüm olan araştırma kısmında yazar, bütün bu gelişmelerin iç hedef kitledeki farkındalığı, memnuniyet düzeyi ve bu gelişmelerin nasıl değerlendirildikleri gibi soruların cevaplarından bahsetmiştir. Bu kısımda Kayseri ilinde yaşayan vatandaşlara basit tesadüfi yöntemle anket uygulanmış, veriler SPSS programı ile analiz edilmiş, katılımcıların demografik verilerine göre farkındalık seviyelerinde ve düşüncelerinde anlamlı farklılar tespit edilmiş ve çıkan sonuçlar üzerine tartı̧̧ma gerçekleştirilmiştir. Yazar sonuç olarak, Türkiye"nin iç hedef kitlesini oluşturan vatandaşların, Türkiye"nin dış hedef kitlesi olan yurtdışındaki vatandaşlara yönelik uyguladığı kamu diplomasisi ve yumuşak güç geliştirme faaliyetlerinden tam olarak farkında olmadıkları, ancak Türkiye'nin bu faaliyetlerini bir gereklilik olarak gördükleri ve bu bağlamda gerçekleştirilen devlet politikalarını destekledikleri sonucuna varmıştır. 


\section{Gaye Aslı Sancar'ın Doktora Tezi}

Uluslararası halkla ilişkiler konusunda iletişim alanında yapılan ilk doktoraçalışması Marmara Üniversitesi Sosyal Bilimler Enstitüsü Halkla İlişkiler ve Tanıtım Anabilim Dalı Halkla İlişkiler Bilim Dalı'nda, Gaye Aslı Sancar tarafından, 2012 yılında "Uluslararası Halkla İlişkiler Yöntemi Olarak Kamu Diplomasisi: Türkiye İçin Bir Model Önerisi" başlığı ile yazılan tezdir. Bu çalışma, konunun iletişim boyutuna değinmekte ve Türkiye'de bir iletişim fakültesi bünyesinde yazılmış ilk doktora tezi olma özelliği taşımaktadır.

Danışmanlığını Prof. Dr. Melda Cinman Şimşek'in yaptığı tezde yazar, giriş, 4 bölüm ve sonuçtan oluşan 401 sayfalık bu çalışmaya bir de İngilizce özet eklemiştir. Sancar, çalışmasında uluslararası halkla ilişkiler yöntemi olarak kamu diplomasisini incelemiş ve tezini bu yönde şekillendirmiştir. Devletlerin diğer devletlerle birebir olan ilişki ve iletişim faaliyetlerinde diplomasiyi, diğer devletlerin halklarıyla olan iletişim faaliyetlerinde ise uluslararası halkla ilişkiler yöntemi olan kamu diplomasisi tekniklerini kullandıklarını ifade eden yazar, Amerika Birleşik Devletleri'nde 20. yy. da sıklıkla kullanılan kamu diplomasisinin Türkiye için yeni bir kavram olduğunu açıklamıştır. Kamu diplomasisinin algı, imaj ve itibar yönetimini etkilediğini ve reaktif davranışların yerine uzun dönemli proaktif davranışları benimsemesi gerektiğini araştırmasında anlatan Sancar, çalışmanın temel amacının dünyadaki gelişmelerle birlikte Türkiye' de bu alanda yapılmak istenen çalışmalara katkı sağlamak olduğunu giriş kısmında belirtmiştir. Ayrıca yazar, kamu diplomasisinin, uluslararası halkla ilişkiler algılama yönetimi, stratejik iletişim yönetimi kavramlarıyla iç içe geçmiş olduğunu ve bu çalışmanın bu karışıklığa son vermede fayda sağlayacağını ifade etmiştir. Sanca'a göre (2012: 347) uluslararası kamuoyunun halkla ilişkiler faaliyetleri aracılığıyla yönetilmesi kamu diplomasisinde kullanılan kilit bir uygulamadır çünkü halkla ilişkilerle ilişkili olan uluslararası halkla ilişkiler, stratejik iletişim yönetimi, algılama yönetimi, imaj ve itibar yönetimi kavramları kamu diplomasisi amaçlarına hizmet etmektedir.

Çalışmanın birinci bölümünde değişen dünyada yeni aktörler ve bunların diplomasideki yeri, devletlerin dış politika aracı olarak diplomasi ve değişen güç kavramı çerçevesinde "sert güç", "yumuşak güç" kavramları ve değişen dünyanın diplomatik ilişkilerinde kamuoyu oluşturmanın önemine değinilmiştir. Yazar, uluslararası halkla ilişkilerin sadece kamuoyu oluşturarak değil gerçekleştirdiği birçok faaliyetle devlet politikalarına meşruiyet sağladığını ifade etmiştir. Bu kapsamda halkla ilişkilerde rızanın üretilmesi ve kamusal alanda meşruiyetin sağlanması Chomsky ve Habermas gibi kuramcılar çevresinde ayrıntılı olarak incelenmiştir (Sancar, 2012:3). İkinci bölümde, uluslararası halkla ilişkiler yöntemi olarak kamu diplomasisi kavramı ayrıntılı olarak incelenmiş, kamu diplomasisinin ABD'de nasıl ortaya çıtığı anlatılarak, kamu diplomasisinde hedef kitle, kaynak, sosyal paydaş ve aktörler anlatılmıştır. Kamu diplomasisi modelleri detaylı olarak ele alınmıştır. Üçüncü bölümde, kamu diplomasisi kavramının uygulama kısmı incelenmiş; kültürel ve yurttaş diplomasisi, lobicilik, savunuculuk ve reklam gibi kamu diplomasisi uygulama alanlarının yanı sıra, geleneksel ve yeni medya, etkinlikler, projeler, ünlü kullanımı, uluslararası yayımcılık ve ulusal markalar gibi araçlar örneklerle açıklanmıştır. Dördüncü bölümde öncelikle Türkiye'nin yumuşak gücü tartışılmış, Türk kamu diplomasisini uygulayan kuruluşlar olarak Başbakanlık Kamu Diplomasisi Koordinatörlüğü, Dışişleri Bakanlığı, Başbakanlık TiKA ve Başbakanlık Yurtdışı Türkler ve Akraba Topluluğu Başkanlığı ve çeşitli sivil toplum kuruluşlarının faaliyetleri örneklerle ele alınmıştır. Türkiye alg1sı ve bununla beraber oluşan imaj ve itibar yönetimi konularında kamu diplomasisinin nasıl bir rol üstlenmesi gerektiği sorusundan yola çıarak; "Propagandanın günümüze uyarlanmış iknaya dayalı bir biçimi olarak kamu diplomasisi uluslararası halkla ilişkilerin anlamlandırıldığı bir neolojizmdir", "Kamu diplomasisi aracılığıyla sert güç uygulamalarına meşruiyet sağlanmaktadır", "Sert güçle kaybedilen güven ve itibar yumuşak güç ile yerine konmaya 
çalışılmaktadır" ve "Sadece sert güce sahip olan uluslar ve gruplar, yumuşak güç uygulayabilir. Yumuşak gücün varlığı ülkenin sert gücüne bağlıdır" hipotezleri gerçekleştirilen derinlemesine görüşmelerle sınanmıştır. Sancar, Başbakanlık Kamu Diplomasisi Koordinatörlüğü, Dışişleri Bakanlığı, Başbakanlık TíKA, uluslararası ilişkiler ve iletişim akademisyenleri ve iletişim danışmanları ile gerçekleştirilen derinlemesine görüşme yöntemi ile toplam 12 kişi ile görüşmüş, ve "Propagandanın günümüze uyarlanmış iknaya dayalı bir biçimi olarak kamu diplomasisi uluslararası halkla ilişkilerin anlamlandırıldığı bir neolojizmdir", hipotezine yönelik olarak sekiz destekleyen, dörtdesteklemeyen nitelikte cevaplar elde etmiştir. Yazar bu ilk hipotez için, derinlemesine görüşmelere katılanların çoğunun kamu diplomasisinin propaganda olduğunu düşünmeseler de, onun halkla ilişkiler olduğunu kabul ettiklerini ortaya koymuştur. Sancar, "Kamu diplomasisi aracılığıyla sert güç uygulamalarına meşruiyet sağlanmaktadır" hipotezine yönelik olarak destekleyen yedi cevap, desteklemeyen dört cevap, bir de tarafsız cevap bulmuştur. Burada katılımcıların çoğunluğunun sert gücün kabulünün yumuşak güç ile sağlanabileceğini ortaya koyduğunu ancak katılımcıların genel kanısının sert gücün hiç kullanılmaması gerektiği görüşünü vurgulamıştır. "Sert güçle kaybedilen güven ve itibar yumuşak güç ile yerine konmaya çalışılmaktadır" şeklindeki üçüncü hipotezi destekleyen dokuz katılımcı varken, desteklemeyen iki katılımc1, soruya tarafsız cevap veren ise bir katılımc1 bulmuştur. Ortaya çıkan genel sonucun, sert gücün gerçek anlamda kullanılmasından ziyade caydırıcı bir güç olarak var olması gerekliliği olduğunu ifade eden Sancar, çalışmada en dikkat çekici sonuçların dördüncü hipotezde olduğunu vurgulamıştır. Dördüncü ve sonuncu hipotezi "sadece sert güce sahip olan uluslar ve gruplar, yumuşak güç uygulayabilir. Yumuşak gücün varlığı ülkenin sert gücüne bağlıdır." olan yazar, beş kişinin bu hipotezi desteklediğini, üç kişinin desteklemediğini ve dört kişinin ise tarafsız kaldığını ifade etmiştir. Hipotezin doğrulanmasına yönelik çok güçlü bir bağ olmadığını ifade eden Sancar, bu hipotezde güçlü bir bağ görülmese de kavramı ortaya atan Nye'ın (2005: 40) daha sonra yumuşak gücü tek başına yeterli görmeyip akıllı güç kavramını ortaya atmasının başlı başına hipotezi desteklemekte olduğunu ve hipotezin kısmen doğrulandığını kabul etmiştir.

Yazar sonuç ve değerlendirme bölümünde geniş literatür çalışmasının ardından, katılımcılara sorulan karşı tarafı dinlemenin nasıl olması gerekliliği, Türk kamu diplomasisinin diyaloğa yönelik olduğunun açıklanması, iki yönlü iletişim için gerekli olan araştırma yöntemlerinin neler olduğunun tartışılması, Türk kamu diplomasisinde dikkat edilmesi gereken noktaları ve model önerisini ortaya koymuştur. Sancar süreç ve modelin doğru uygulandığında Türkiye'nin yumuşak gücünü yaşadığı sorunlar karşısında doğru şekilde kullanabileceğini, Türk kamu diplomasisinin ilk olarak araştırma, daha sonra politikaların gözden geçirilip stratejilerin belirlenmesi, mesajların hazırlanması ve iletileceği araçların belirlenmesi, karşılıklı uygulamalara olanak verilmesi, diyalog ve tekrar araştırma sürecinin benimsenmesinin mümkün olduğunu ifade etmiştir.

\section{Gonca Yıldırım'ın Doktora Tezi}

Danışmanlığını Prof. Dr. Ayla Okay'ın yaptığı, İstanbul Üniversitesi Sosyal Bilimler Enstitüsü Halkla İlişkiler ve Tanıtım Anabilim Dalı'nda, 2014 yılında Gonca Yıldırım tarafından yazılmış tez "Uluslararası Halkla İlişkiler Perspektifinden Kamu Diplomasisi: Türkiye Kamu Diplomasisi Koordinatörlüğü (KDK) Örneği Çerçevesinde Kültürel Diplomasi"dir. Giriş, dört bölüm, ingilizce özet ve sonuç kısmından oluşan tez 445 sayfalıktır ve amacı uluslararası halkla ilişkiler bakış açısıyla kamu diplomasisine yaklaşmak ve her iki disiplinin modellerinin de karşılıklı olarak ele alınması, uygulama alanlarının da incelenmesidir. Araştırma kısmında incelenen kamu diplomasisinin temeli olan yumuşak gücün ayaklarından birini oluşturan kültürel diplomasi esas 
alınmış, Türkiye Kamu Diplomasisi Koordinatörlüğü'nün faaliyetleri kültürel diplomasi çerçevesinde içerik analiz yöntemiyle çözümlenmeye çalışılmış, ortaya çıkan bulgular ışığında Türkiye için kültürel diplomasiye yönelik bazı öneriler geliştirmiştir.

Bu tezin birinci bölümünde yapılan literatür taramasıyla halkla ilişkilerin kamuoyu ve kamusal alan yaratılmasındaki rolü irdelenmiş, Halkla İlişkiler Toplumsal Yaklaşım Teorileri, Organizasyon Teorisi Yaklaşımları ve kamu diplomasisi teorileri karşılaştırılmış, kesişim noktaları değerlendirilmiştir. Yazar bu bölümde ayrıca uluslararası halkla ilişkilerin gelişimini etkileyen faktörleri, uluslararası halkla ilişkilerin aktörlerini ve uluslararası halkla ilişkiler uygulamalarında kullanılan sistematiği ortaya koymaya çalışmıştır. Çalışmanın ikinci bölümünde küreselleşme ve günümüz dünyasının değişen koşullarına paralel olarak değişen toplumsal yapılar, sistem aktörleri ve kamu diplomasisinin önemi ele alınmıştır. Bu bağlamda kamu diplomasisi modelleri, uygulama alanları ve ilişkili olduğu disiplinler bu bölümün içeriğini oluşturmuştur. Tezin üçüncü bölümünde yazar, kültürün özelliklerini, öğelerini, küreselleşme çağında kültürler arası ilişkileri ele almıs, Türk kültürünün bu yapıyı nasıl taşıdığı, Türkiye'nin uyguladığı kültür politikaları ve bunların kamu diplomasisi dahilinde ele alınışını incelemiştir. Dördüncü yani araştırma bölümünde ise yazar; Osmanlı ve Türkiye'deki diplomasi anlayışı ile başlamakta ve günümüz KDK ve faaliyetlerini ele almaktadır. Deibel ve Roberts, Zaharna, Cull, Signitzer ve Coombs'un kamu diplomasisi modellerinden yola çıarak siyasal enformasyon ve kültürel diplomasi bağlamında oluşturulan araştırma kategorileri ve ölçekleri içerik analizi yöntemi ile incelenmiş, KDK'nın faaliyetlerinde kültürel diplomasinin hangi boyut ve ölçüde kullanıldığı tespit edilmeye çalışılmıştır. Sonuç olarak Yıldırım'ın yaptığı bu araştırma ve sonuçları ışığında Türkiye'nin uygulayabileceği kültürel diplomasi çalışmaları konusunda öneriler geliştirilmiştir.

Çalışma kapsamında kamu diplomasisinin yıllara dayanan değişim süreci, ele alınış şekliyle uzmanların gözünde yarattığı olumlu-olumsuz görüşler, çeşitli alanlardaki uygulama şekilleri ve diğer disiplinlerle ilişkisini inceleyen Yıldırım, bu çalışmanın önemini uluslararası halkla ilişkilerle kamu diplomasisi kuram ve pratiklerinin karşılıklı ele alınması olarak ifade etmiştir. $\mathrm{Bu}$ çalışma kamu diplomasisine halkla ilişkiler boyutundan yaklaşımı desteklemektedir. Yazar araştırma sorununu; KDK kültürü, kültürel öğeleri ve Türk kültürel kodlarını yani kültürel diplomasiyi etkin dış politika yaratmak ve farklı toplumları etkileyerek, Türkiye'yi tanıtmakta ne ölçüde kullanmaktadır? Türkiye kamu diplomasisi vizyonu ile kültürü nasıl daha iyi kullanabilir? olarak, araştırmanın sınırlılığını ise KDK'nın Ocak 2010 - Aralık 2013 tarihleri arasında gerçekleştirdiği kültürel diplomasi çalışmalarının değerlendirilmesi olarak belirlemiştir. Bu çalışmanın evrenini Türkiye Cumhuriyeti hükümetinin uluslararası tanıtım faaliyetlerinin tamamı oluşturmaktadır. Tüm bu çalışmaların içinden ve özellikle kamu diplomasisine hizmet etmesi amaciyla kurulan KDK ve faaliyetleri inceleme kapsamında örneklem olarak seçilmiştir. Kültürel diplomasi ve siyasal enformasyon birleşimi şeklinde ele alınan kamu diplomasisi çerçevesinde öncelikle kültürel diplomasi ve siyasal enformasyona yönelik kodlar belirlenip, bunların Koordinatörlüğün etkinlikleri dahilinde ele alınış şekli, kullanılma oranları tespit edilerek içerik analizi yöntemiyle değerlendirilmiştir. Bu çalışmada belirtilen yıllar arasında gerçekleşen etkinlikler resmi web sitesinden takip edilmiş, irdelenmiş ve ayrıntılı olarak niceliksel ve niteliksel bir analiz yapılmıştır. Bu yöntem ışığında, kültürel diplomasiyi oluşturan öğeler ile KDK'nın bu öğeleri nasıl kullandığına dair değerlendirme yapabilmek için bazı ölçekler geliştirilmiştir. Yıldırım (2014: 317-322), araştırmada KDK'yı seçerken kamu diplomasisi konusunda Türkiye'de en yetkin birim olmasını belirleyici nokta olarak ele almıştır. Çalışmada KDK'nın resmi sitesinde bulunan "Faaliyetler" başlıklı sekmesinde yer alan, Kasım 2010- Aralık 2013 tarihleri arasında gerçekleştirilen ve web ortamında kamuya aktarılan 104 adet faaliyet analiz edilmiştir. Yazar, içerik analiziyle elde ettiği bulgulara göre KDK'nın faaliyetlerinin \%89 
gibi çok büyük bir oranının siyasal enformasyon odaklı yürütüldüğünü, kültürel diplomasi faaliyetlerinin kamu diplomasisi faaliyetlerinin toplamının \%11 gibi az bir oranın oluşturduğunu belirtmiştir. Bu bulgular "Kamu diplomasisi faaliyetleri ağırlıklı olarak siyasal enformasyon odaklı yürütülmektedir, kültürel diplomasiye gereken önem verilmemektedir" varsayımlarını doğrulamaktadır. Bu sonuç aynı zamanda "KDK kültürel kodları kamu diplomasi faaliyetlerinde ne kadar kullanıyor? Kültürel diplomasi faaliyetlerinin kamu diplomasisi faaliyetlerinin toplamına yansıması nedir?" sorularının da cevabını vermektedir. Kamu Diplomasisi Koordinatörlüğü faaliyetleri çerçevesinde kurumun web sitesinden incelenen 104 adet faaliyete ilişkin genel bir değerlendirme yapan Yıldırım; faaliyetlerin \%27'sinin Üniversite Programları, \% 53'ünün Siyasal İletişim Faaliyetleri, \%27'sinin Medya-Tanıtım Çalışmaları olarak yapıldığını ortaya koymuştur. Faaliyetler, alt başlıklarına göre değerlendirildiğinde kamu diplomasisinin anlatıldığı paneller, Türk dış politikasının tanıtıldığı tanıtım programları, gençlik programları, Türk iç ve dış politikasının anlatıldığı ülke toplantıları, gazeteci heyetleri programları, yabancı basını bilgilendirme programlarının hepsinin siyasal enformasyon amaçlı olduğu görülmüştür. Akil İnsanlar Konferansları, Küresel Forum ve Avrupa Toplantılarının ise Türkiye ve dünya siyasi ve sosyal gündemini oluşturan konuların tartışıldığı, görüş bildirildiği toplantılar olduğu yazar tarafından belirtilmiştir. Yıldırım, değerlendirme bölümünde özetle, KDK faaliyetlerinin Türkiye'nin yeni iç ve dış politikasına ilişkin yoğun bir ikna ve bilgilendirmeye yönelik söylem ve faaliyetleri \%89 oranla öne çıkarken, kültürel diplomasiye dönük olarak tespit edilen faaliyet ve söylemlerin oranı \%11 olarak bulunduğunu ifade etmiştir. $\mathrm{Bu}$ sonuçlar araştırmanın başlangıcında sorulan "Kamu diplomasisi faaliyetlerinde kültürel öğelerin oranı, yansıması, bu öğelere ne kadar önem verildiği" sorularına verilmiş bir cevap niteliği taşımaktadır.

\section{Pınar Aslan'ın Doktora Tezi}

2018 yılında, İstanbul Üniversitesi Sosyal Bilimler Enstitüsü Halkla İlişkiler Anabilim Dalı'nda, Pınar Aslan tarafından, Prof. Dr. Yıldız Dilek Ertürk danışmanlığında "Bir Uluslararasi Halkla İlişkiler Stratejisi Olarak Kültür ve Yaratici Endüstri Ürünleri: Latin Amerika Pazarinda Türk Dizileri Üzerine Bir Araştirma" başlığı ile yazılan tez 213 sayfadan oluşmaktadır. Giriş, dört bölüm, sonuç kısmı, bir de ingilizce özet eklenen bu çalışmanın amacı Türk televizyon dizilerinin yurt dışında, özellikle de Latin Amerika sektöründeki başarısının incelenmesi ve bu etkinin olası sonuçlarının belirlenmesi olarak ifade edilmiştir. Yazar, Türk televizyon dizilerini 2014 yılında Şili'de başlayan Latin Amerika pazarında uluslararası halkla ilişkiler, kamu diplomasisi, kültürel diplomasi, yumuşak güç ekseninde analiz etmiş, Türk televizyon dizilerini yaratıcı kültür endüstrisi ürünü olarak ele almış ve kültür ürünlerinin Şili'de elde ettiği başarıları uluslararası halkla ilişkiler çerçevesinde değerlendirmiştir.

Çalışmanın birinci bölümünde, uluslararası halkla ilişkiler kavramı detaylı bir şekilde incelenmiş ve itibar yönetimi, yumuşak güç, kültürlerarası iletişim gibi kilit kavramlarla ilişkilendirilmiştir. İkinci bölümde kamu diplomasisi kavramıla kültürel diplomasi arasındaki bağ ve dünyada ve Türkiye'de kamu diplomasisi irdelenmiştir. Üçüncü bölümde kültür, popüler kültür ve kültür endüstrisi kavramları sonrasında kültür ve yaratıcı endüstrilerin günümüzde geldiği durum ele alınmış, tez çalışmasının araştırmasını içeren dördüncü bölümde ise televizyon dizileri yaratıcı kültür endüstrisi olarak incelenmiş, Türk televizyon dizilerinin yurt dışındaki başarısı değerlendirilmiştir. Ayrıca Latin Amerika'da Türk televizyon dizilerinin yayımlandığı ilk ülke olan Şili'de Türk dizilerinin başarısı örnek olay tekniğiyle incelenmiş, sonrasında Şili'de derinlemesine görüşmelerin sonuçlarına yer verilmiştir. Türk televizyon dizilerinin Latin Amerika dizi sektörüne entegre olma süreci sebep ve sonuçlarıyla ele alınmıştır. 
Aslan (2018: 139), yaptığı derinlemesine görüşmelerin sonucunda Türk dizilerinin Şili'de 2014 yılından beri Türkiye ve Türk kültürüne dair bir bilgi akışı sağladığı, önyargıları ortadan kaldırmaya yaradığı, Türkiye' nin yumuşak gücünü arttırdığı ve bu nedenle uluslararası halkla ilişkiler stratejisi olarak değerlendirilmesi gerektiği sonucuna varmıştır. Ulaşılan bulgular doğrultusunda, Türk dizilerinin Şili'de büyük bir başarıya ulaştığı ve bu başarının Türkiye'nin yumuşak gücüne ciddi oranda etki ettiği gözlemlenmiştir. Bunun nedenini yazar, Latin Amerika'da 2014 yılından beri Türk televizyon dizisi izleyenlerde Türkiye'ye dair bir merak, yakınlık ve hayranlık olduğuna hatta derinlemesine görüşmelerde Türkiye'ye seyahat etmeyi isteyip istemedikleri, Türk müziğine ve modasına ilgileri hakkında sorulan sorulara tüm katılımcıların olumlu cevap vermesiyle ilişkili olduğuna bağlamıştır. Aslan'a göre yumuşak gücün giderek önem kazandığı günümüzde Türkiye'nin de bu güce ciddi oranda ihtiyacı olduğu, Türkiye'nin uluslararası markalarının çok az olması, müzik ve spor gibi alanlarda edindiği başarıları sürdürebilir kılamaması gibi nedenlerle yumuşak güç kaynağının Türk dizileri olduğu söylenebilir. Bu sebeple, Türk dizilerinin bir kültür endüstrisi ürünü olarak ele alınması gerektiğini, bu çerçevede de ölçümleme, planlama ve sürekli değerlendirmeye dayanacak çalışmaların Türkiye'nin yumuşak gücünü desteklerken Türk dizilerinin uluslararası başarısını da sürekli kılacak iki yönlü bir fayda sağladığını ifade etmiştir.

\section{Hande Gözüm'ün Doktora Tezi}

2018 yılında, “Uluslararası Halkla İliş̧iler ve Kamu Diplomasisi: Soğuk Savaş Döneminde Türkiye - Amerika Birleşik Devletleri İlişkileri Örneği" başlıklı tez Gazi Üniversitesi Sosyal Bilimler Enstitüsü Halkla İlişkiler ve Tanıtım Anabilim Dalı'nda Hande Gözüm tarafından yazılmıştır. Danışmanlığını Prof. Dr. Tuğba Asrak Hasdemir' in yaptığı tez giriş, ingilizce özet, üç bölüm ve sonuç olmak üzere 174 sayfadan oluşmaktadır.

Çalışmanın amacının, kamu diplomasisi tarihini detaylı irdeleyerek tanımlamak ve açıklamak olduğunu ifade eden Gözüm aynı zamanda, kamu diplomasisini, Truman Doktrini ve Marshall Planı ile kurumsallaşmaya başlayan Amerika Birleşik Devletleri ile Türkiye ilişkileri ekseninde, uluslararası halkla ilişkiler faaliyeti olarak ele almaktadır. Giriş bölümünde araştırmanın amacı, önemi, sınırlılıklarından bahseden yazar birinci bölümde, uluslararası halkla ilişkiler kavramı ele almış, uluslararası toplumsal rızanın inşası, güç, uluslararası politikalarda meşruiyetin sağlanması konusunu irdelemiştir. İkinci bölümde araştırmanın sınırlılığını da oluşturan Truman Doktrini ve Marshall Planı'nın kamu diplomasisi bağlamında değerlendirilmesi üzerine yoğunlaşan yazar, kamu diplomasisi aracı olan Amerikan yardımlarından da bahsetmiştir. Üçüncü bölümde Marshall Planı Filmlerini analiz edip çözümleme yapmıştır. Yazar güç, diplomasi, hegemonya, ikna söylemi, propaganda gibi kavramların kamu diplomasisi uygulamaları ile arasındaki ilişkiyi de analiz etmiştir.

Gözüm'e göre (2018: 98) ABD, kamu diplomasisini uluslararası halkla ilişkiler etkinliği olarak kullanmayı keşfeden ve önemli bir dereceye kadar da uygulama ölçütlerini belirleyen devlettir. Bu nedenle yazar, 1945 yılından itibaren ABD'nin kamu diplomasi söylemini hangi çerçevede planladığı, ABD'nin Türkiye'ye uyguladığı kamu diplomasi pratiğinde, Türkiye'ye ve Türk halkına hangi mesajları verdiği, ABD'nin, kamu diplomasi pratiği olarak hangi araçları kullandığı, Soğuk Savaş döneminde etkin biçimde kullanılan kamu diplomasisi pratiğinin son yıllarda neden tekrar popüler bir faaliyet haline geldiği ve günümüzde kamu diplomasi pratiğinin hangi araçlarla uygulandığı sorularına cevap aramıştır. Sonuç olarak yazara göre, politikalara destek sağlama, olumlu alg1 oluşturma ve sürdürülebilir ilişki inşa etme süreçlerinden oluşan kamu diplomasisinin yumuşak güç üreten bir ülke tarafından, uluslararası politikada kullanılabilecek etkin bir araç olduğu ifade edilmiştir. Günümüz uluslararası 
ilişkilerinde, başta Amerikan hegemonyası olmak üzere, söz sahibi diğer uluslararası ya da bölgesel aktörler daha baskın hale gelmiş ve uyguladıkları politikalar çevresinde gittikçe azalan bir meşruiyete sahip olmaya başlamışlardır.

\section{Fikret Soner'in Doktora Tezi}

Fikret Soner' in "Uluslararasi Halkla İlişkiler Çerçevesinde Oluşturulan Gastrodiplomasi Modeli: Türkiye İncelemesi ve Öneriler" başlıklı tezi, Maltepe Üniversitesi, Sosyal Bilimler Enstitüsü, Halkla İlişkiler ve Tanıtım Anabilim Dalı'nda, 2020 yılında, Dr. Öğr. Üyesi Gülseli Aygül Alan danışmanlığında yazılmıştır. 268 sayfadan oluşan tez, giriş, ingilizce özet, üç bölüm, bulgu ve yorumlar ve sonuçtan oluşmaktadır. Yazar çalışmanın odak noktasının gastrodiplomasi kavramının kamu diplomasisi, uluslararası halkla ilişkiler, kültürel diplomasi alanları ile ilişkisinin ortaya konulması olduğunu belirtmiştir. Ayrıca gastrodiplomasinin bir model olarak ortaya konulmasıyla, kamu diplomasisi alanı içinde yer alan çeşitli aktörlerin farkındalığının tespitine olanak sağlanacağı görüşündedir. Gastrodiplomasiyi kamu diplomasisi ana başlı̆̆ altında, kültürel diplomasi kümesinin içinde ele alan yazar, bu araştırması ile oluşturduğu gastrodiplomasi modeli eşliğinde Türkiye Cumhuriyeti Devleti'nin ilgili kurumlarının gastrodiplomasi konusuna olan ilgisi, uygulamalarmın tespiti ve seviyesinin belirlenmesini hedeflemiştir. Araştırma çerçevesinde gastronominin bileşenlerinden yola çıkılarak oluşturulan gastrodiplomasi modeli eşliğinde, devlet kurumlarının belirleyici rolünün ortaya konması ve yapılan görüşmeler yoluyla farkındalığın tespit ve inşa edilmesi amaçlanmıştır. Toplanan veriler ile mevcut durum tespit edilmiş ve öneriler geliştirilmiştir.

Birinci bölümde, uluslararası halkla ilişkiler ve kamu diplomasisi kavramları irdelenmiş, ulus markası ve ulus kimliği kavramları kamu diplomasisi ile ilişkilendirilmiştir. Yine birinci bölümde yazar, kültürel diplomasi kavramından bahsetmiş ve Türkiye'nin kamu diplomasisi ve kültürel diplomasi yaklaşımına değinmiştir. Son olarak gastrodiplomasiden bahseden yazar, ikinci bölüme geçmeden önce gastrodiplomasi modeli geliştirmiştir. Yazara göre uluslararası halkla ilişkiler, kamu diplomasisi ve kültürel diplomasi etrafında konumlandırılan gastrodiplomasi; boyutları, bileşenleri ve yüksek ekonomik değer yaratma potansiyeli ile hem birey ve kuruluşların hem de devletlerin faaliyet ortamında yer almaktadır. Soner'in ürettiği gastrodiplomasi modelinde, devletin ve devlet dışı sivil oluşumların alanları yatay ve dikey olarak şekillenen iki farklı, fakat birbirleriyle bağlantılı ortam olarak gösterilmektedir. Modelde yatay alanda yasal düzenleme, liderlik, destek, pazarlama ve sürdürülebilirlik yer alırken, dikey alanda imaj ve itibar, iletişim, kurumsallaşama, tanıtım ve satı̧, gurur ve destek faaliyetleri yer almaktadır (2020: 107). İkinci bölümde yazar, araştırmanın yönteminden, modelinden, evren ve örnekleminden, verilerin elde edilip analiz edilmesinden bahsetmiştir. Bulgu ve yorumların ele alındığg üçüncü bölümde Soner, T.C. Kültür ve Turizm Bakanlığı, T.C Tarım ve Orman Bakanlığı, T.C. Ticaret Bakanlığı, T.C. Dışişleri Bakanlığı, Cumhurbaşkanlığı İletişim Başkanlığı, TASAM Türkiye Asya Stratejik Araştırmalar Merkezi, TíM Türkiye İhracatçılar Meclisi, TURYİD Turizm Restaurant Yatırımcıları ve Gastronomi İşletmeleri Derneği, TAFED Türkiye Aşçılar Federasyonu, "Yeni Anadolu Mutfağı" Mikla, Mehmet Gürs gibi görev kapsamına kültür, tarım, ticaret ve dış politika, turizm ana bileşenlerinin girdiği devlet kurumlarının ve sivil toplum temsilcilerinin web sitelerinde, 2019 yılı içerisinde yüklenmiş olan strateji belgesi, eylem planı, faaliyet raporu, çalıştay veya zirve toplantıları sonuç raporları, kamuya yapılan duyuru niteliğindeki belgeleri incelemiştir. Araştırmanın veri toplama sürecinde ikinci aşamayı, örneklemi oluşturan ve devlet teşkilatı içerisinde kamu diplomasisi ve kültürel diplomasi bağlamında gastrodiplomasiyi uygulayacak kurumların üst düzey yöneticileri ve yakından ilgili görülen sivil toplum kuruluşları yetkilileri ile gerçekleştirilecek derinlemesine görüşmeler 
oluşturmaktadır. Soner bu amaçla, TURYID Başkanı, TAFED Yönetim Kurulu Başkanı ve Şef Mehmet Gürs ile yaptı̆̆ 1 görüşmeler ile gastrodiplomasi modelinin dikey boyutunda yer alan sektörlerdeki farkındalığı ortaya koymayı, devletten beklentiyi anlamayı ve devletin uygulamalarının yarattığı etkiyi belirlemeyi hedeflemiştir.

Araştırma sonucu olarak, örneklem grubunda yer alan sivil toplum kuruluşlarının gastrodiplomasi konusunda farkındalığının devlet kurumlarından daha yüksek olduğu ve devlet ile sektörü çeşitli vesilelerle bir araya getirdikleri görülmüş, kanaat önderi konumunda olarak veya strateji üreterek devlet kurumlarının dikkatini çekmekte oldukları anlaşılmıştır. Yazar, kurumsal web sitelerini incelemesi sonucunda, gastrodiplomasi modelinde devlet kurumlarına verilen fonksiyonlar bakımından, Dışişleri Bakanlığı'nın destek ve pazarlama, Kültür ve Turizm Bakanlığı'nın pazarlama (tanıtım), sürdürülebilirlik, liderlik, Tarım ve Orman Bakanlığı'nın liderlik, destek, Ticaret Bakanlığı'nın destek ve pazarlama konularında öne çıkmış oldukları kanısına varmıştır. Soner'e göre, kamu diplomasisi alanında konumlandırılan gastrodiplomasi, imaj ve itibar yönetiminde bir araç ve yaklaşım olarak sunulmakta aynı zamanda temelinde derin kökler de barındırmaktadır. Bununla birlikte yazar, Türkiye'nin gıdayı ilk sıralara alarak hareket edilmesinin geleceğin şekillenmesinde fayda sağlayacağı ve yasa koyup denetleyen, destekleyen bir devlet yapısının bütüncül bir anlayışla, sektörel stratejiler ve politikalar üreterek yön verdiği, liderlik ettiği bir ortamda, gastrodiplomasinin bütün bileşenleri ile hayat bulabileceği kanısındadır.

\section{SONUÇ}

YÖK resmi internet sitesinde yapılmış olan tarama sonucunda iletişim disiplini içinde uluslararası halkla ilişkiler konusunda yazılan dokuz tez incelendiğinde; genel hatları ile yazıldıkları yıllarda uluslararası halkla ilişkiler kavramını detaylı olarak ele aldıkları, günümüz şartlarında değerlendirildiğinde ise farklı boyutlar açısından ele alınmaya başladığı ve iletişim disiplinine özel olarak alana pozitif katkıda bulundukları söylenebilir. İncelenen bu dokuz tez çalışmasının daha sonra yapılacak tezlere öncülük edeceği söylenebilir.

Tezlerde genel olarak, halkla ilişkileri, uluslararası halkla ilişkileri, kültürel diplomasi ve kamu diplomasisi ilişkisine vurgu yapıldığı ve uluslararası halkla ilişkilerin sadece iletişim alanında değil siyaset bilimibağlamında kamu diplomasisi için de ne kadar önemli olduğu işlenmiştir. Tezlerde ortak olarak bahsedilen konular, uluslararası halkla ilişkiler yöntemi olarak kamu diplomasisi kavramı ve aralarındaki ilişkidir.

Yazılan tezlerin tümünde ilk olarak literatür taraması yapılmış, araştırma ile ilgili bilgi içeren kaynak ve belgeler sistematik şekilde incelenmiş ve betimlenmiştir. Nadide Aslı Dede tarafından yazılan ilk yüksek lisans tezinin yöntemi derinlemesine görüşme iken, Sibel Karakaya'nın tezi anket çalışmasıdır. Zeynep İmrak durum analizi yaparak örnek olay incelemesi gerçekleştirmiştir. Tarık Kodal tarafından yazılmış olan tezde nicel yöntemlerden anket çalışması kullanılmıştır. Gaye Aslı Sancar tarafından yazılan ilk doktora tezinin yöntemi derinlemesine görüşme olurken, Gonca Yıldırım tarafından yazılmış üçüncü tezin yöntemi ise içerik analizidir. Pınar Aslan tezinde örnek olay incelemesi ve derinlemesine görüşme tercih ederken, Hande Gözüm örnek olay incelemesi gerçekleştirmiştir. Uluslararası halkla ilişkilerle ilgili yazılan son tez Fikret Soner tarafından hazırlanan çalışmadır ve yazar araştırmasında örneklem olarak seçtiği kurumlarla derinlemesine görüşmeler yapmış ve gastrodiplomasi üzerine bir model oluşturmuştur.

Tezlerde iletişim teknolojilerinin ve uluslararası ticaretin gelişmesiyle birlikte halkla ilişkilerin boyut değiştirdiği, farklı coğrafyalarda bulunan farklı kamulara hitap edebilmenin, uluslararası 
toplumu bir şekilde etkilemenin ve yönlendirmenin en önemli araçlarından birinin uluslararası halkla ilişkiler olduğu belirtilmektedir. Aynı zamanda devletlerin uluslararası halkla ilişkilerin, uygulamalarıyla rıza üretimini gerçekleştirdiği, uluslararası halkla ilişkiler yöntemi olan kamu diplomasisi ile sıkı bir ilişki içinde olduğu, bir ülkenin çıarlarını gözetme ve dış kamuoyu oluşturma anlamında kamu diplomasisi kadar etkili bir yöntem olduğu vurgulanmıştır. Buradan yola çıkarak iletişimin giderek önemli hale geldiği toplumlarda dünyadaki bütün ülkelerin uluslararası halkla ilişkiler faaliyetlerinden faydalanmaya çalışmasının normal olduğu söylenebilir.

İncelenen dokuz tezde de halkla ilişkilerin uluslararası ilişkiler alanında kamu diplomasisi ile birlikte anıldığı, uluslararası halkla ilişkilerin ve kamu diplomasisi alanlarının ilgi çerçevesi ve gündemlerinin çoğu kez birbiri ile aynı olduğu ifade edilmektedir. Uluslararası halkla ilişkiler, alg1 yönetimi, imaj ve itibar yönetimi, stratejik iletişim yönetimi gibi kavramlar kamu diplomasisine katkı sağlayan alanlar olarak değerlendirilmektedir. Akademik yazında ve uygulamada kapsamı ve çerçevesi farklı şekillerde tanımlanan uluslararası halkla ilişkilerin devletle ilişkili boyutuna da dikkat çekilmektedir. Tezlere göre uluslararası halkla ilişkiler faaliyetleri, kriz yönetimi kampanyaları, küresel şirketler için geliştirilen iletişim ve kurumsal kimlik stratejileri ile hükümetler tarafından yürütülen, dış politika amaçlarını gerçekleştirmede ve uluslararası kamuoyunda olumlu alg1 yaratmada ciddi öneme sahip faaliyetlerdir. Yazarlar, uluslararası halkla ilişkiler faaliyetlerinin hem devletlerin uluslararası kamuoyunu yönetirken kullanacakları araç görevi üstlendiğini belirtmiş hem de hükümetlerarası ilişkiler, uluslararası örgütler, ulusaşırı ekonomik faaliyetler ve farklı ulus halkları arasındaki etkileşimler gibi alanları kapsadığını ifade etmişlerdir. Bununla birlikte uluslararası arenada halkla ilişkilerin etkili ve verimli sonuçlar alınacak şekilde uygulanabilmesinin, uygulayıcıların diğer ülkelerin kültür ve değerler sistemlerine, siyasi ve ekonomik yapılarına yönelik bilgi ve ilgisinin artmasına bağlı olduğu kansına varılmıştır. Tezlerde uluslararası halkla ilişkiler faaliyetlerini kullanan devletlerin, kurum veya kuruluşların bu bağlamda kendi kültürel, sosyal ve ekonomik değerlerini kamuoyuna anlatmayı aynı zamanda siyasi olarak iç ve dış politikaları konusunda uluslararası kamuoyunu bilgilendirmeyi amaçladıkları vurgulanmıştır.

Halkla ilişkilerin uluslararası boyutu olan uluslararası halkla ilişkiler ve geleneksel diplomasiden farklı, yumuşak gücün tabanı olan kamu diplomasisi arasında bir ilişki olduğunu vurgulayan tezlerde, özellikle sosyal bilimlerde bir araştırmacının olayları tam olarak tarafsız şekilde değerlendirmesinin ve sonuçlara ulaşmasının mümkün olmadığı ifade edilmiştir. Bunun en önemli örneğinin, halkla ilişkilerin ve kamu diplomasisinin bazı uygulayıcıları propaganda ve rıza yaratma aracı olarak görüp bazılarını da ilişki, diyalog ve işbirliği yöntemi olarak tanımlaması olduğu belirtilmiştir. Bu tezlere göre gerek halkla ilişkilerde gerek kamu diplomasisinde bazı kavramların anlaşılmasında ve algılanmasında tarihsel süreçlerden de kaynaklanan önyargıların bulunduğu, her iki kavramın da sıklıkla propagandanın örtülü biçimleri olarak değerlendirildiği ifade edilmiştir. Son yıllarda özellikle kendini iyi ifade edemeyen, yanlış algılanan ve hakkında ön yargılara sahip olduğu söylenen Türkiye'nin de uluslararası halkla ilişkiler kavramını göz ardı etmemesi gerektiği, sahip olduğu yumuşak güç kaynaklarını iyi değerlendirmesi gerektiği ifade edilmiştir.

\section{KAYNAKÇA}

Arklan, Ü. ve Akdağ, M. (2010). Halkla İlişkilerin Pusulast: Politika. e-Journal of New World Sciences Academy Humanities, 1(5), 1-21. 
Aslan, P. (2018). Bir Uluslararasi Halkla İlişkiler Stratejisi Olarak Kültür ve Yaratici Endüstri Ürünleri: Latin Amerika Pazarinda Türk Dizileri Üzerine Bir Araştirma, Doktora Tezi, İstanbul Üniversitesi, İstanbul.

Culbertson. H. M. (2009). Introduction, International Public Relations. Hugh M. Culbertson ve Ni Chen. (Eds.) 2. Basım, New York, Routledge.

Dede, N.A. (1997). Uluslararası Halkla İlişkilerde Küresel Düşün fakat Yerel Davran ve Levi Strauss \& Co. Türkiye Örneği, Yüksek Lisans Tezi, İstanbul Üniversitesi, İstanbul.

Gözüm, H. (2018). Uluslararası Halkla İlişkiler ve Kamu Diplomasisi: Soğuk Savaş Döneminde Türkiye - Amerika Birleşik Devletleri İlişkileri Örneği, Doktora Tezi, Gazi Üniversitesi, Ankara.

Hiebert, R. E. (2005). Commentary: Challenges for Arab and American public relations and public diplomacy in a global age. Public Relations Review, 31(3), 317-322.

Holtzhausen, D.R. (2011) The Need for a Postmodern Turn in Global Public Relations, Nilanjana Bardhan ve C. Kay Weaver (ed.), Public Relations in Global Cultural Contexts. New York: Routledge, $140-166$.

https://tez.yok.gov.tr/UlusalTezMerkezi/tezSorguSonucYeni.jsp> [Erişim Tarihi: 11.12.2020].

İmrak, Z. (2012). Çokuluslu işletmelerde Uluslararası Halkla İlişkiler Faaliyetleri: Taşımacılık Sektöründen Deutsche Post DHL Üzerine Bir İnceleme, Yüksel Lisans Tezi, İstanbul Üniversitesi, İstanbul.

Karakaya, S. (2006). Uluslararasi Halkla Ilişkiler: Antalya'da Küçük ve Orta Ölçekli Işletmeler ile T.C. Yurtdisi Ticaret ve Ekonomi Müşavirlikleri'nde Bir Araştirma, Yüksek Lisans Tezi, Akdeniz Üniversitesi, Antalya.

Kartarı, A. (2000). Kültürlerarası İletişim Çalışmalarının Üniversite Disiplin Olarak Gelişimi: Münih Üniversitesi Kültürlerarası İletişim Kürsüsü 'nün Doğuşu. 1. Ulusal İletişim Sempozyumu Bildiri Özetleri. Ankara: Ankara Üniversitesi İletişim Fakültesi, Gazi Üniversitesi İletişim Fakültesi.

Kodal, T. (2016). Uluslararası Halkla İlişkiler Bağlamında Yumuşak Güç: Üç Hedef Kitle Üzerine Bir Araştırma, Yüksek Lisans Tezi, Erciyes Üniversitesi, Kayseri.

Köksoy, E. (2013). Halkla İlişkiler Bağlamında Kamu Diplomasisi Yönetimi Türkiye'nin Kamu Diplomasisindeki Yetkinlik İncelemesi, Doktora Tezi, İstanbul Üniversitesi, İstanbul.

Lassalle, E. (1959). Problems in international public relations. The International Executive, 1(2), 5-6. doi:10.1002/tie.5060010203

McLuhan, M. (2001). Global Köy. İstanbul: Scala Yayıncilık.

Moore, H. F. and Kalupa, F. B. (1985). Public Relations Principles, Cases and Problems. Ninth Edition, Homewood, Illionis: Richard D. Irwin, Inch.

Nye, S. J. (2005). Soft Power: The Means to Success in World Politics. Public Affairs, C anada.

Okay, A. ve Okay A. (2001). Uluslararası Halkla İlişkiler. İstanbul Üniversitesi İletişim Fakültesi Dergisi, 11: 267-298.

Phair, J. (2011). Crossing borders: How to establisb an international PR program. Public Relations Tactics, 6:18

Pratt, Cornelius B. and Ogbondah, W. Chriss (1996). International Public Relations education: US. Issues and Perspectives. International Public Relations: A Comparative Analysis. M. Hugh 
Culbertson, and Chen Ni (der.) içinde. Mahwah, New Jersey: Lawrence Erlbaum Associates Publishers. 381-195.

Sancar, G. A. (2012). Uluslararası Halkla İlişkiler Yöntemi Olarak Kamu Diplomasisi: Türkiye İçin Bir Model Önerisi, Doktora Tezi, Marmara Üniversitesi, İstanbul.

Soner, F. (2020). Uluslararası Halkla Illişkiler Çerçevesinde Oluşturulan Gastrodiplomasi Modeli: Türkiye İncelemesi ve Öneriler, Doktora Tezi, Maltepe Üniversitesi, İstanbul.

Sriramesh, K. and Vercic, D. (2002). International public relations: A framework for future research. Journal of communication management, 6(2), 103-117.

Tench, R. and Yeomans, L. (2006). Exploring Public Relations. England: Prentice Hall.

Wilcox, D. L. and Cameron, G. T. (2006). Public Relations Strategies and Tactics. 8. Basim, USA: Boston, Allyn and Bacon.

Yıldırım, G. (2014). Uluslararası Halkla İlişkiler Perspektifinden Kamu Diplomasisi: Türkiye Kamu Diplomasisi Koordinatörlüğü Örneği Çerçevesinde Kültürel Diplomasi, Doktora Tezi, İstanbul Üniversitesi, İstanbul.

Yıldırım, G. (2015). Uluslararası Halkla İlişkiler Perspektifinden Kamu Diplomasisi. 1. Baskı. İstanbul: Beta Yayıncilik. 